\title{
Factors influencing flower bud formation on the pear tree cultivar 'Doyenne du Comice' \\ II. Influence of growth inhibition on the anatomical structure of the stem
}

\author{
FRANCISZKA JAUMIEŃ
}

Department of Pomology, Warsaw Agricultural University (SGGW), Nowoursynowska 166, 02-766 Warszawa, Poland

(Received: October 13, 1980)

Abstract

Differentiation of the particular tissues in shoots inhibited in growth by chlormequat occurs differently than in vigorously growing ones. After the end of elongation growth, in the subapical part of shoots sprayed with chlormequat the cortex extends and secondary xylem develops less intensively, this leading to an increased participation of parenchymatous tissue in the stem.

\section{INTRODUCTION}

The investigations of $\mathrm{B}$ e a k b a $\mathrm{n} \mathrm{e}$ and $\mathrm{R}$ e $\mathrm{n} \mathrm{w} \mathrm{i} \mathrm{c} \mathrm{k} \mathrm{(1936),} \mathrm{B}$ e a kb a n e and Thomps o n (1939), B e a k b a n e (1941) demonstrated that there is a relation between the anatomical structure of roots and stem of the rootstock in apple trees and the vigour of growth and fruiting of the scion, grafted on it. Weakly growing rootstocks on which the trees started fruiting early showed on the cross section of the shoot or root a higher percentage of living tissue surface than did the vigorously growing ones. This was due to an increased surface of cortex and xylem rays and a reduced diametre of vessels. $\mathrm{S} \mathrm{c} \mathrm{h} \mathrm{u} \mathrm{m} \mathrm{a} \mathrm{c} \mathrm{he} \mathrm{r} \mathrm{et} \mathrm{al.} \mathrm{(1967)} \mathrm{and} \mathrm{H}$ a lf a c r e and B a r de n (1968) noted similar differences in the anatomical structure of the internodes in apple tree shoots inhibited in growth by SADH and the strongly growing ones.

SADH affected cell division and increased the parenchymatous cells volume in shoots and leaves of cultivar 'Golden Delicious' and 'York Imperial'. The diametres of the parenchymatous cells of the pith and cortex were significantly larger, and those of the vessels significantly smaller on cross sections of shoots treated with SADH than in shoots of control trees. On the cross sections of shoots 
of the 'York Imperial' cultivar sprayed with SADH the number of parenchymatous pith and cortex cells was several times higher, and the number of vessels much lower than in the control shoots ( $\mathrm{H} \mathrm{a} 1 \mathrm{f} \mathrm{a} \mathrm{c} \mathrm{r} \mathrm{e} \mathrm{and} \mathrm{B} \mathrm{a} \mathrm{r} \mathrm{d} \mathrm{e} \mathrm{n}, 1968)$.

The present study was undertaken to establish the changes in the anatomical structure of the stem preceding setting of flower buds on pear shoots sprayed with chlormequat as compared with the control shoots vigorously growing on which flower buds usually do not form, and with spurs.

\section{METHODS}

The influence of growth inhibition of shoots sprayed with chlormequat on the anatomical structure of the stem was studied on cross sections at mid length of on internode of the subapical, the middle and the basal part of three shoots treated with chlormequat and tree untreated ones (spraying method described in part I) and under the apical bud of three spurs of control trees. Material was collected in June and July 1972, 1973 and 1975 and fixed in 70 per cent ethyl alcohol. Cross sections of 16-20 $\mu$ thickness were stained with Fuchsin S, and Malachite green. Microscopic observations were done each time on three sections.

Microscopic measurements of the width of the cortical layer (from cork to phloem fibers), of phloem (jointly with fibers and cambium), of xylem and pith were performed along three radii on each section of the shoots examined in 1972. Means from nine measurements corresponding to the three shoots were used for calculating the ratio of phloem to xylem width and the percentual proportion of the width of each measured tissue to the length of the radius of the cross section of the stem. The pith was measured along the maximal and minimal diametre. For calculations one half of the mean of these measurements was used.

\section{RESULTS}

Anatomical structure of the stem in June

The anatomical structure of the pear stem did not differ essentially from that of the apple or plum tree. The shoots sprayed with chlormequat differed from the unsprayed ones by the structure of the internode. In mid June there prevailed in the internodes of the subapical part of the control shoots with a typical structure for rapidly elongating internodes, parenchymatous cells forming a broad pith $(48 \%)$ and cortex $(29 \%)$ with scarce calcium oxalate crystals. Vascular tissue occupied in that part of the shoots only 23 per cent of the radius length (Table 1). Beside well developed phloem with broad cambium zone, but still without fibers, protoxylem vessels just beginning to differentiate were visible (Fig. 1a). The ratio of phloem (with cambium) to xylem (Ph:X) width was in this case 2.27. 
Fig. 1

$100, \mu m$

a)

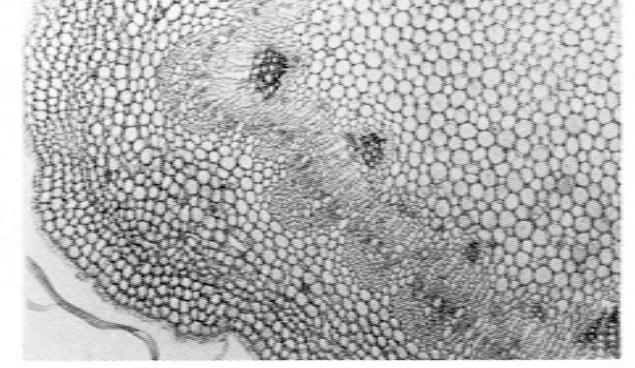

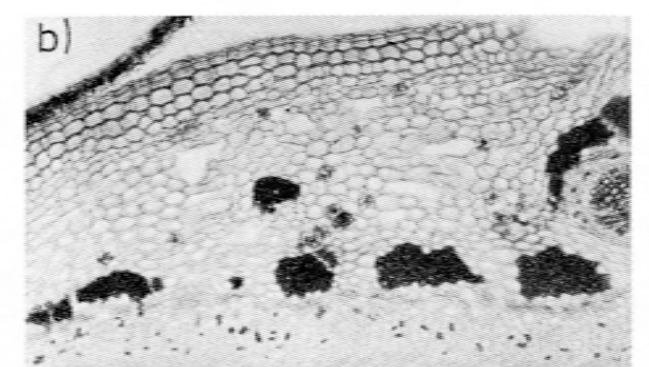

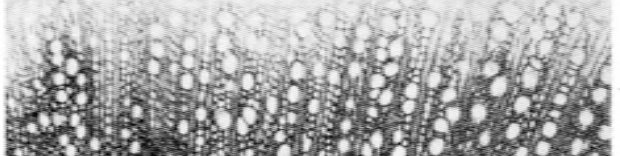

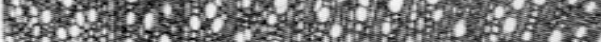

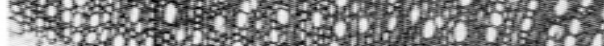

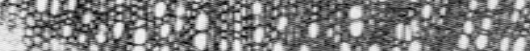

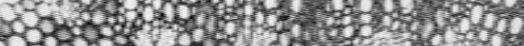
Ho HK\% Hot3 3010200000 - 0005 . +0003000

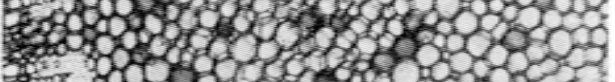

c)

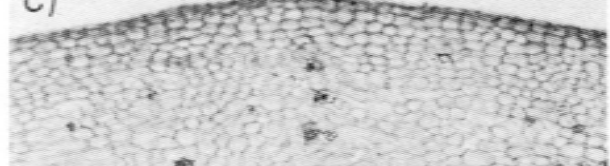

3.

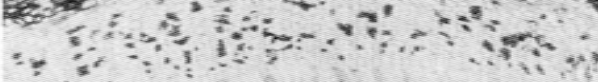

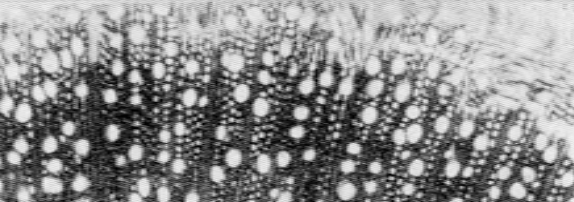
69 os on $10 \%$

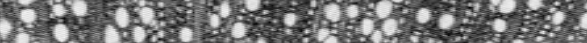

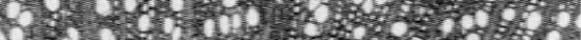

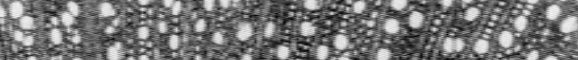

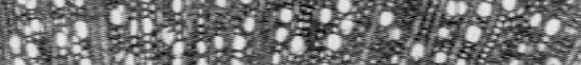

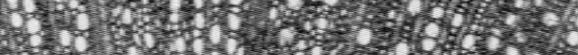
29.0 H H.

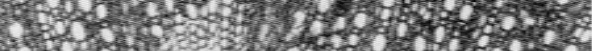
7.1.

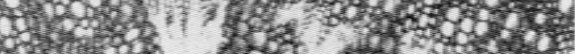

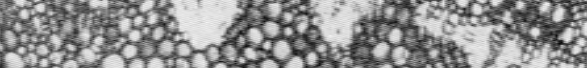

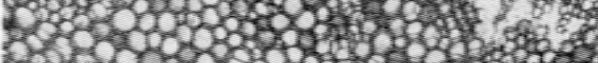

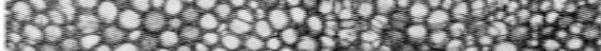

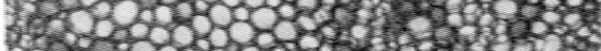
2808038 . 1083351 \% 
Fig. 2

c)

$100 \mathrm{~nm}$

Ary

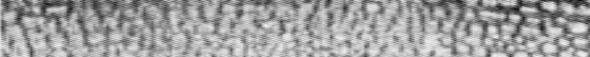
217.

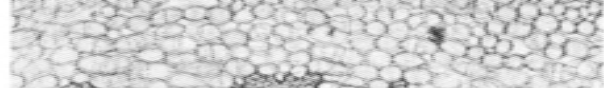

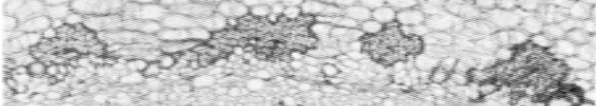

a)

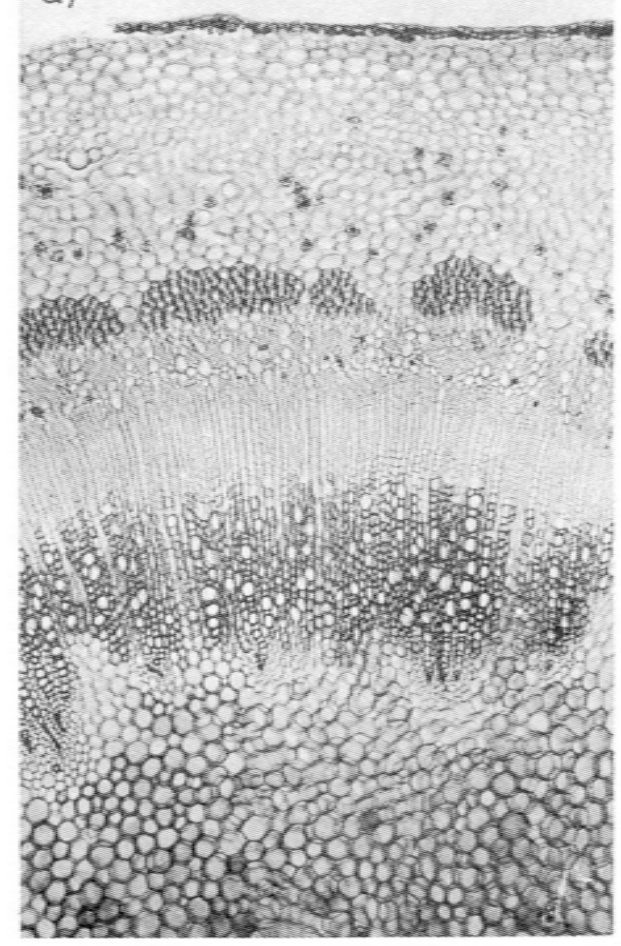

b)

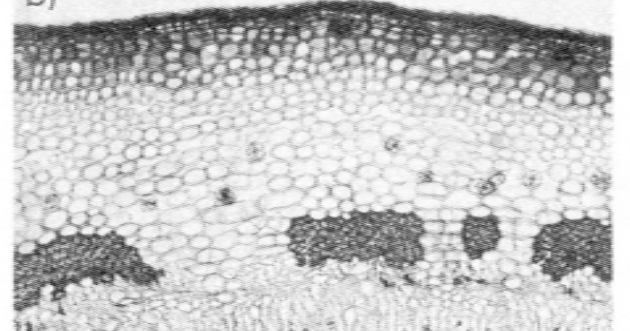

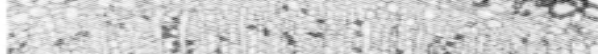

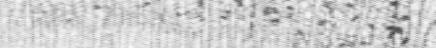

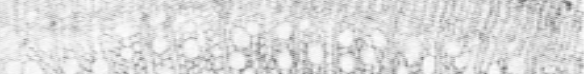
Con

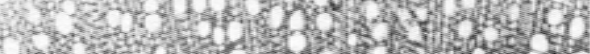
3. 5

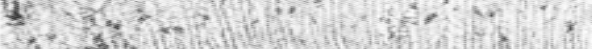

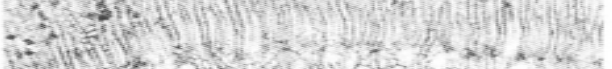

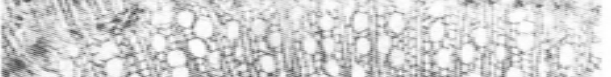

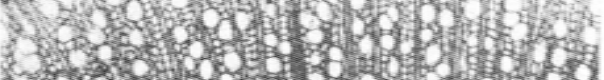

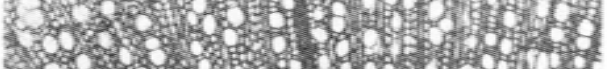

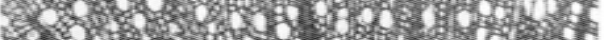
on 1 .

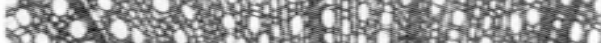
Wor

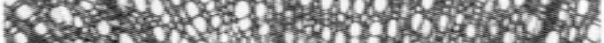

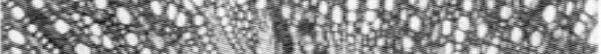

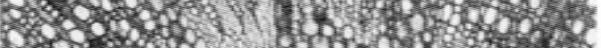

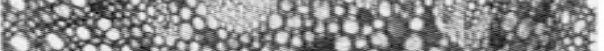

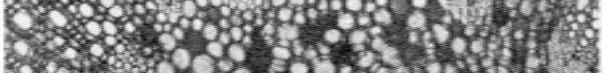

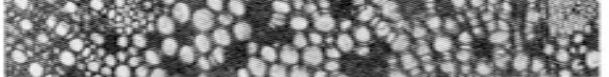

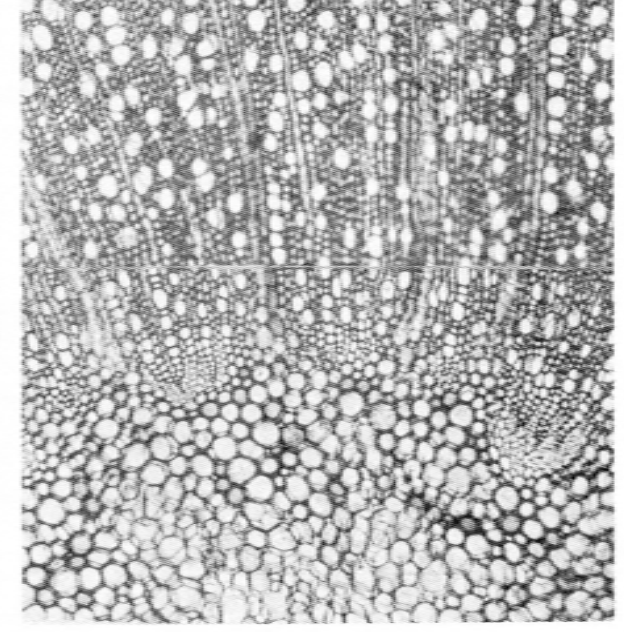




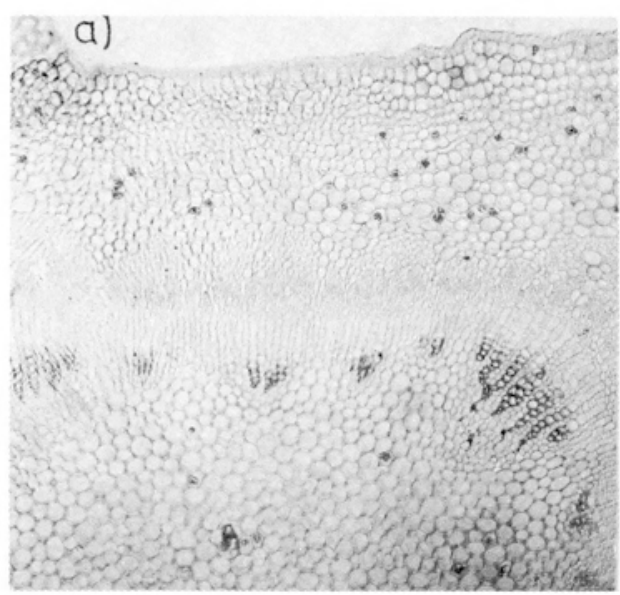

b)
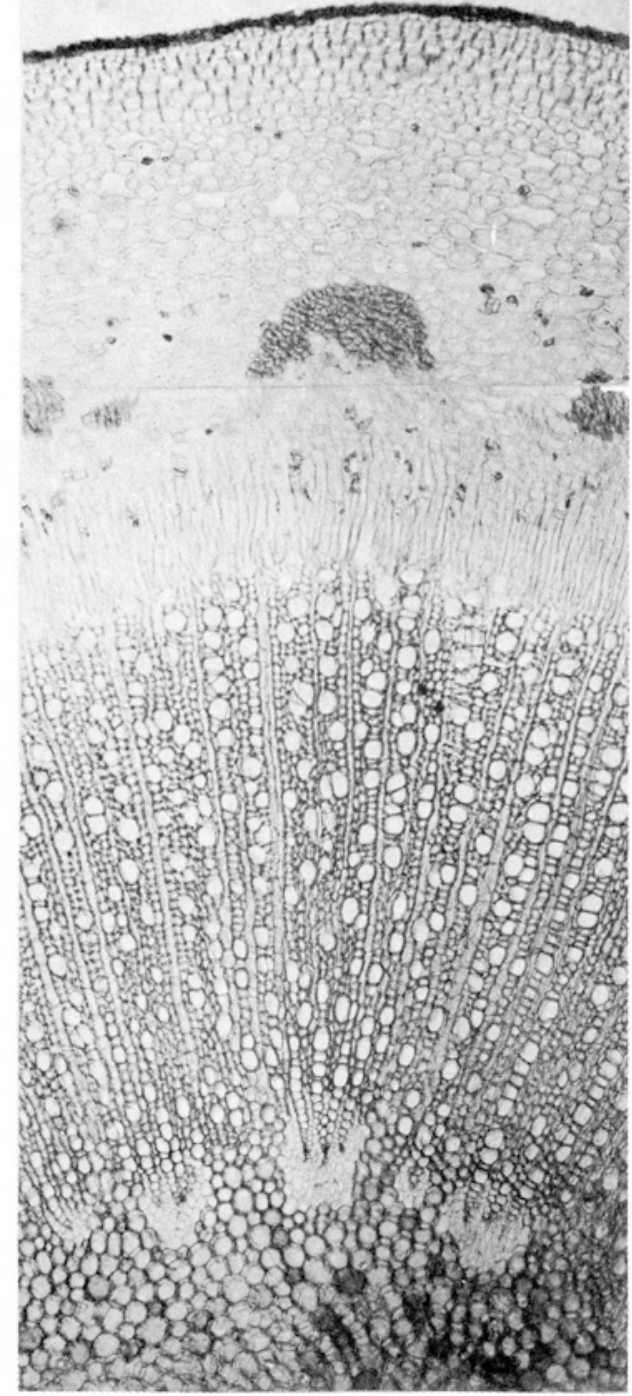

\section{$\lceil 100 \mu \mathrm{m}$}

Fig. 3

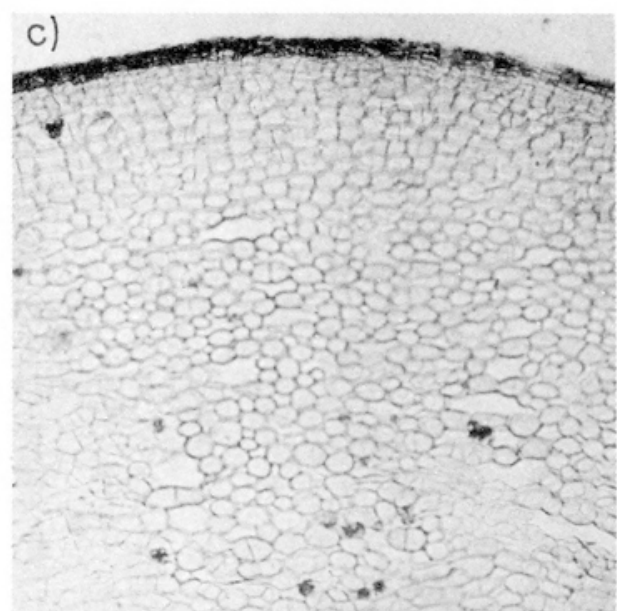

5.

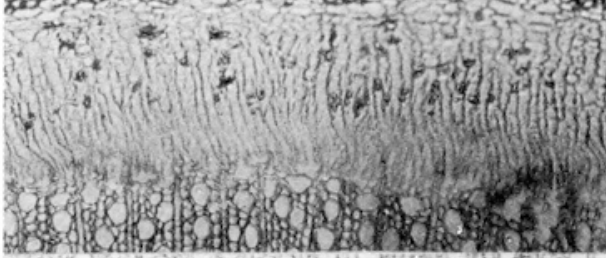
सCW W 4. Jit ( ve

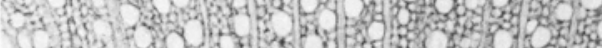

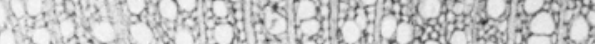
6. $\mathrm{x}$.

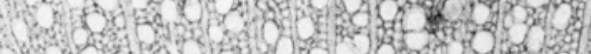

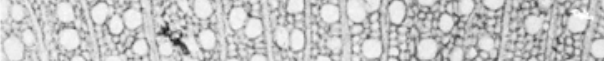
स.

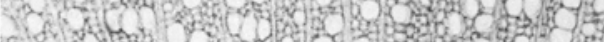

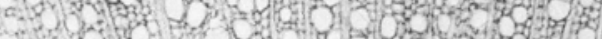
whin Sav +1. 5. -

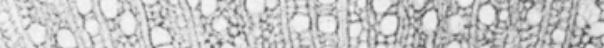
(2) W

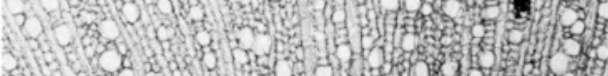

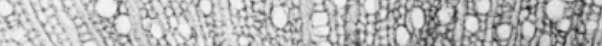

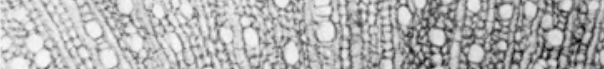

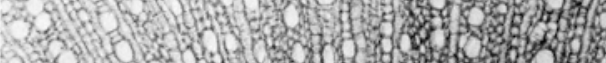

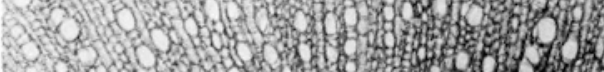

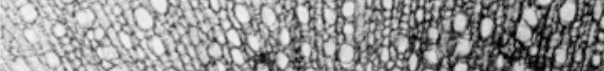

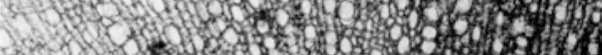
X d

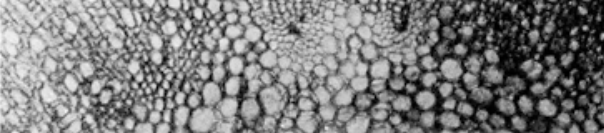


Fig. 4

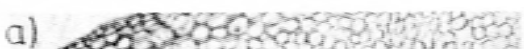

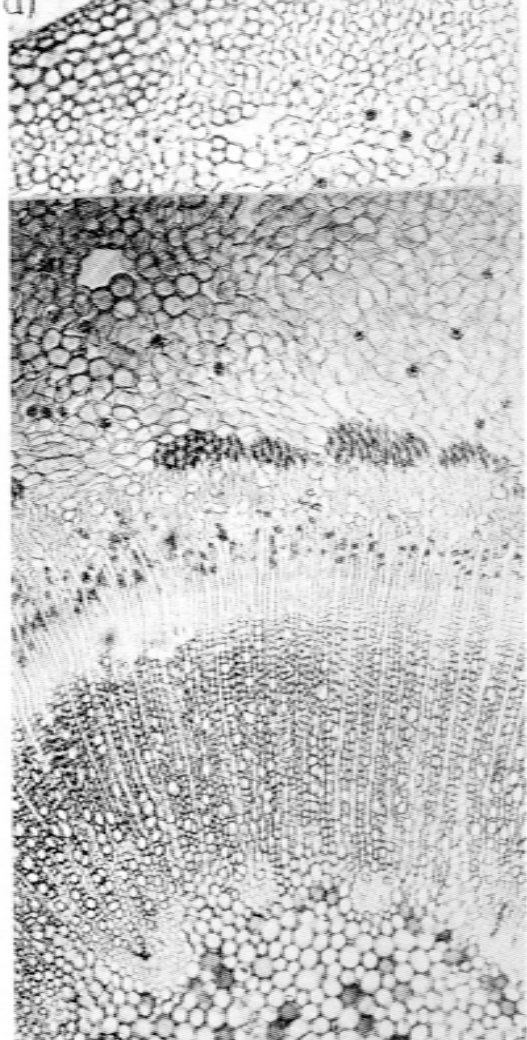

$100 \mathrm{\mu m}$

b)

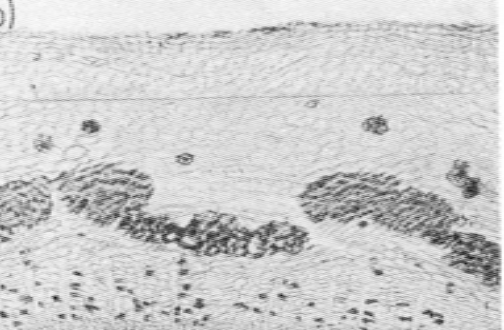

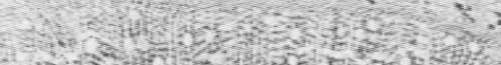
if 34 y Hitn the

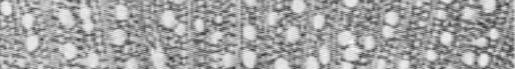

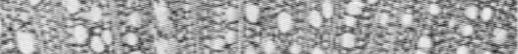

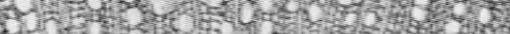

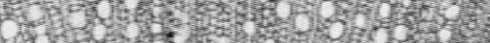
Q

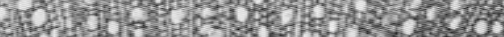

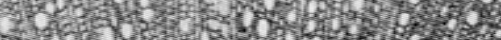
Th

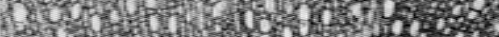
H.

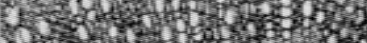

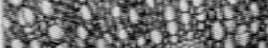
G 101506 c)

Hofer of

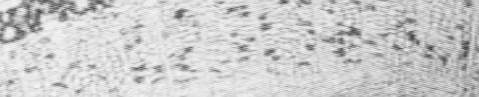

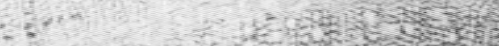

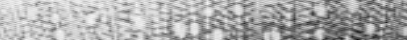

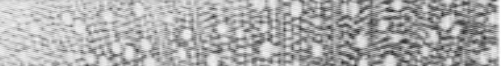
Arting

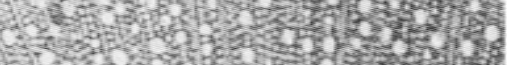

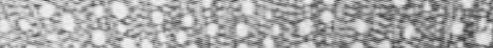

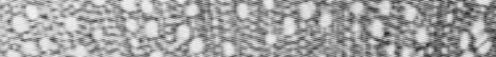
3f औ. 5 -

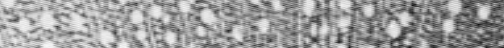

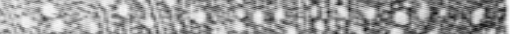

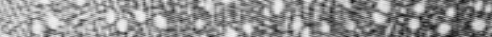

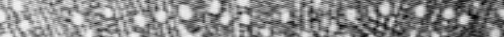

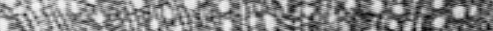

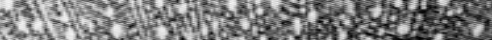

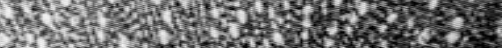

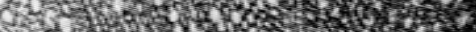

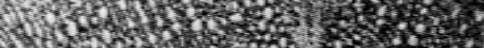

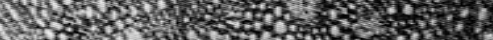
SI Hot 

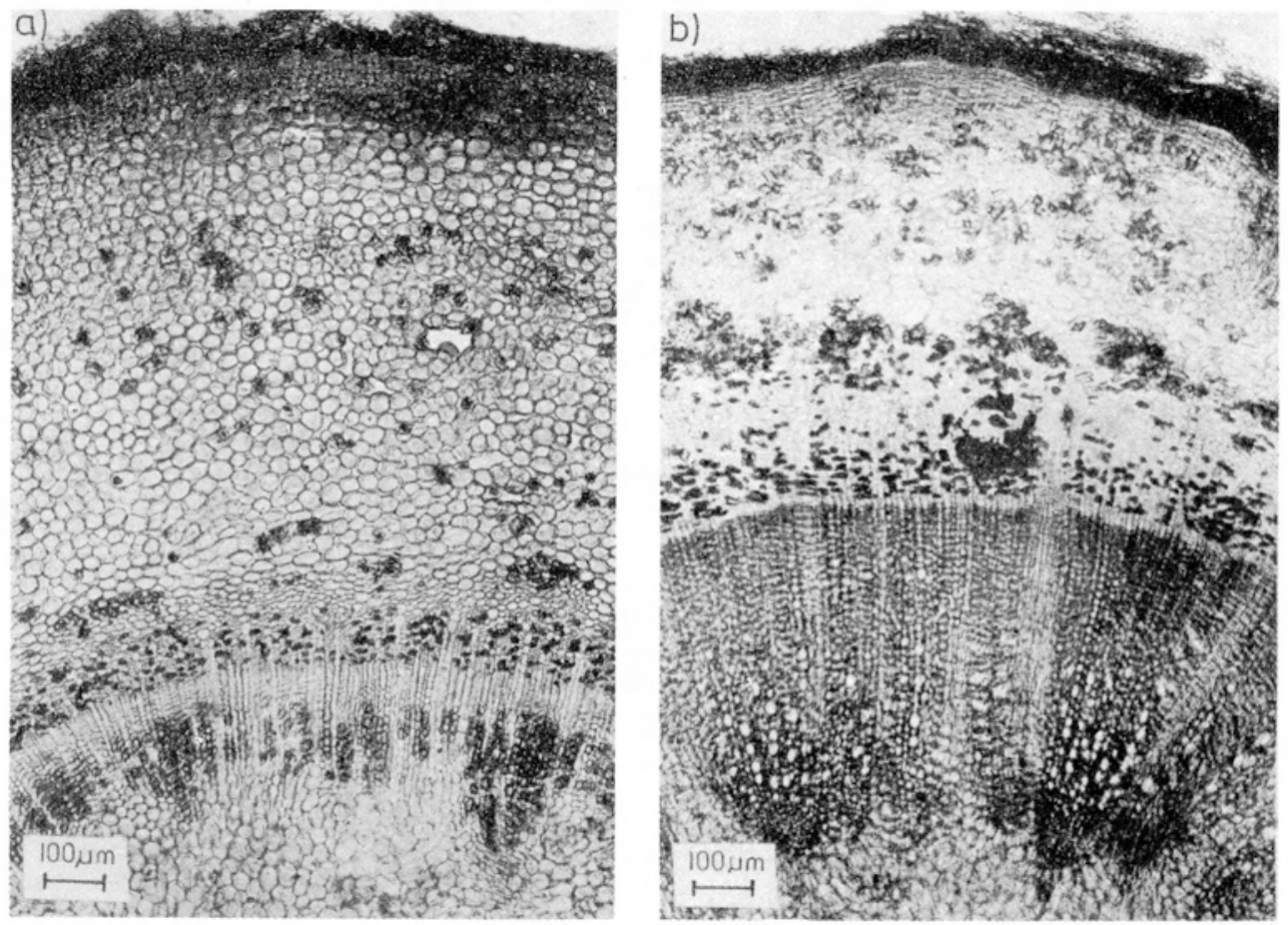

Fig. 5. Cross sections of spurs showing anatomical structure of pear tree stem characterized by weak elongation growth: a - mid June, b - mid July 
Fig. 1. Cross sections of control shoots showing the anatomical structure of the pear tree stem in the period of intensive elongation growth (mid June): a - subapical part, $\mathrm{b}$ - middle part, $\mathrm{c}$ - basal part

Fig. 2. Cross sections of shoots sprayed with chlormequat showing the anatomical structure of the pear tree stem in the period of slowed down elongation growth (mid June): a - subapical part, b - middle part, c - basal part

Fig. 3. Cross sections of control shoots, showing the anatomical structure of the pear tree stem continuing elongation growth in mid July: a - subapical part, $\mathrm{b}$ - middle part $\mathrm{c}$ - basal part

Fig. 4. Cross sections of shoots sprayed with chlormequat showing the anatomical structure of the pear tree stem in mid July after the end of elongation growth: $\mathrm{a}$ - subapical part, $\mathrm{b}$ - middle part, $\mathrm{c}$ - basal part 
Ta b l e 1

Ratio of phloem (Ph) to xylem (X) width and percentual proportion of width of cortex (C), phloem, xylem and half of pith (P), to length of cross section radius length in subapical, middle and basal part of shoots unsprayed and sprayed with chlormequat in the period June-July 1972

\begin{tabular}{|c|c|c|c|c|c|c|c|}
\hline \multirow{2}{*}{$\begin{array}{l}\text { Numerical and } \\
\text { percentual } \\
\text { ratio }\end{array}$} & \multicolumn{3}{|c|}{ Control shoots } & \multicolumn{3}{|c|}{$\begin{array}{l}\text { Shoots sprayed } \\
\text { with chlormequat }\end{array}$} & \multirow{2}{*}{$\begin{array}{l}\text { Control } \\
\text { spurs }\end{array}$} \\
\hline & apex & middle & base & apex & middle & base & \\
\hline \multicolumn{8}{|l|}{17 June 1972} \\
\hline $\mathrm{Ph}$ and $\mathrm{X}$ & 2.27 & 0.40 & 0.31 & 0.68 & 0.40 & 0.35 & 0.80 \\
\hline $\mathrm{C}$ & 29 & 17 & 15 & 26 & 15 & 16 & 38 \\
\hline $\mathrm{Ph}$ & 15 & 15 & 14 & 15 & 15 & 14 & 12 \\
\hline $\mathrm{X}$ & 8 & 38 & 43 & 23 & 39 & 40 & 15 \\
\hline $\mathrm{P}$ & 48 & 30 & 28 & 36 & 31 & 30 & 35 \\
\hline \multicolumn{8}{|l|}{17 July 1972} \\
\hline $\mathrm{Ph}$ and $\mathrm{X}$ & 2.00 & 0.36 & 0.22 & 0.76 & 0.32 & 0.24 & 0.72 \\
\hline $\mathrm{C}$ & 31 & 16 & 18 & 31 & 15 & 16 & 28 \\
\hline $\mathrm{Ph}$ & 12 & 15 & 11 & 15 & 14 & 12 & 17 \\
\hline $\mathrm{X}$ & 7 & 42 & 48 & 20 & 44 & 50 & 23 \\
\hline $\mathbf{P}$ & 50 & 27 & 23 & 34 & 27 & 22 & 32 \\
\hline
\end{tabular}

At mid length of control shoots in the no more elongating internodes the primary phloem fibers are already visible in mid June and developed secondary xylem with 1- or, less frequently, 2-row rays and vessels with a large lumen. In cortex cells and in the phloem there occur numerous calcium oxalate crystals. A layer of collenchyma forms under the epidermis (Fig. 1b). At this level of the shoot vascular tissue occupies more than 50 per cent of the cross section radius, and cortex and pith occupy jointly about 47 per cent. Xylem forms a much broader zone than does phloem so that the width ratio $\mathrm{Ph}$ to $\mathrm{X}$ is as low as 0.40 (Table 1).

In the basal part of unsprayed shoots (Fig. 1c) the xylem band occupies about 43 per cent of the cross section radius. As the result of a sligth increase in secondary phloem the $\mathrm{Ph}: \mathrm{X}$ ratio in this part of the shoot is lowest $(0.31)$. The thickness increment of cortex is also small. Phloem with dense calcium oxalate crystals is surrounded from outside by a continuous band of fibers and sclereids. Cambial tissue is much narrower then in the subapical, like in the middle part of the shoot.

Shoots sprayed with chlormequat ended elongation growth much earlier than the control shoots. Cross sections showed in mid June in the upper part of these shoots differentiating and lignifying phloem fibers and secondary xylem elements, this indicating the end of internode elongation in the subapical part of these shoots. The width of the vascular tissue constituted 38 per cent of the stem cross section radius, and the $\mathrm{Ph}: \mathrm{X}$ ratio was 0.68 (Table 1). Fibres with thickening walls are visible, the cambium zone is very broad and there is a rather 
wide layer of differentiating secondary xylem. Rather dense in it are many-rowed rays, but vessels are less numerous and their lumen is smaller than that of secondary xylem vessels of control shoots. Cortex is more differentiated in the subapical part of the sprayed shoots than in the untreated ones. In the parenchymatous cells close to the phloem there are numerous calcium oxalate crystals, and under epidermis a 4 - 5 collenchyma layers similarly as in the middle part of the control shoots. Numerous intercellular space are also visible (Fig. 2a).

The anatomical structure of the middle and basal part of the shoots sprayed with chlormequat (Fig. 2b, c) does not differ practically from that of the control shoots, however, in the middle part of treated shoots the xylem is less lignified (Fig. 2b) than in the control shoots (Fig. 1b). The ratio of phloem to xylem width in this part of the shoots is the same or similar as in the basal part of shoots treated with chlormequat and control ones (Table 1).

The spurs characterized by weak elongation growth of short duration showed in mid June a very wide cortex with numerous calcium oxalate crystals and intercellular spaces, surrounded from outside by a cork and collenchyma layer (Fig. 5a). The band of cortex occupies at this time about 38 per cent the vascular tissue about 27 per cent of the shoot cross section radius and the pith about 35 per cent (Table 1). The Ph:X ratio is here lower than in the subapical part of the control shoots $(0.80)$ and higher than in this part of shoots with growth inhibited by chlormequat (0.68). Fibers are lacking in the phloem, instead of them cells are present with large single calcium oxalate crystals. Numerous such crystals are also visible in secondary phloem. Xylem forms a rather homogeneous tissue. There are no elements in it or very few with a wide lumen. One-, 2-, and 3-row rays are visible.

\section{Anatomical structure of stem in July}

In mid July, when the elongation growth of the control shoots was weaker, but still continued, a 4-layer collenchyma was visible and more numerous than in June calcium oxalate crystals in the cortex (Fig. 3a). The central part of these shoots exhibits an early stage of tissue differentiation after the end of elongation growth. A very wide band of secondary not completely lignified xylem is visible and primary phloem fibers with lignified middle lamella (Fig. 3b). In the basal part of the shoots there is much secondary xylem containing vessels with a large lumen and mostly single rays. Dilatation divisions are visible in the cortex parenchyma and collenchyma connected with the widening of the stem (Fig. 3c).

Shoots treated with chlormequat completely ended elongation growth at the beginning of July. In mid July cell division in all directions appeared in the extending cortex of the subapical part of these shoots. Such a phenomenon 's not observed in control shoots (Fig. 4a). Associated with it is the formation of larger intercellular spaces and thickening of the shoots. Very numerous calcium oxalate 
crystals are visible in the secondary phloem. The fibers are poorly developed and not joined by sclereids into a continuous layer, they may even not be present at all. The cambial layer is much narrower than in June, while the increment of secondary xylem is higher. There are no typical vessels in the xylem or only scarce ones with a small lumen, particularly close to the cambium.

In the middle and basal part of sprayed shoots the fibers together with sclereids form an almost continuous ring surrounding the phloem (Fig. 4b, c). There are somewhat more numerous calcium oxalate crystals than in June. In the part of xylem adjacent to the cambium the elements with a large lumen are less numerous than in the earlier period.

In the spurs of control trees vascular tissue is most developed (Fig. 5b) in mid July. Numerous calcium oxalate crystals appear in the cortex and the site of fiber formation. They fill almost completely the secondary phloem. The xylem band with densely arranged rays is several times wider than in June. At least in half of the xylem width in its outer part elements with large lumen are in general absent and closer to the pith scarce vessels occur with lumen smaller than in the xylem of the control long shoots.

\section{DISCUSSION}

On the basis of the present results it may be stated that the anatomical structure of the pear tree stem does not differ from that of apple and plum tree stems (M a z u r o w a, $1969 \mathrm{a}, \mathrm{b}$ ). The investigations demonstrated a distinct effect of growth inhibition on the anatomical structure of the pear tree stem. Shoots sprayed with chlormequat end their elongation growth much earlier than the untreated ones. Owing to this, differentiation of the particular tissues in these shoots has a different course. The differences are already noticeable in June and marked in mid July. After completion of elongation growth widening of cortex occurs in the subapical part of stems treated with chlormequat caused by the divisions of cells in all directions within it and the formation of large intercellular spaces. Thickening of the upper part of the stem is very characteristic for shoots treated with retardants ( $\mathrm{S} \mathrm{c} \mathrm{h} \mathrm{u} \mathrm{m} \mathrm{a} \mathrm{c} \mathrm{h} \mathrm{e} \mathrm{r} \mathrm{et} \mathrm{al.,} \mathrm{1967).} \mathrm{H} \mathrm{a} \mathrm{lf} \mathrm{a} \mathrm{c} \mathrm{r} \mathrm{e} \mathrm{and}$ $\mathrm{B}$ a $\mathrm{r}$ d e $\mathrm{n}$ (1968) explain this phenomenon for apple trees sprayed with SADH by stimulation of cell division and an increase of the width of parenchymatous cell width in the cortex and pith, and $\mathrm{W}$ i $1 \mathrm{~d}$ e and $\mathrm{E} \mathrm{d} \mathrm{g} \mathrm{e} \mathrm{r} \mathrm{t} \mathrm{o} \mathrm{n} \mathrm{(1969)attribute}$ it to a change in the direction of cell division under the influence of SADH from transverse to longitudinal, transverse and oblique and to the formation in this connection of numerous intercellular spaces.

The proportions of the width of basic tissues on the cross section of the subapical part in shoots with growth inhibited by chlormequat and in spurs which naturally grow weakly is very similar and different than in the vigorously growing shoots. After the end of internode elongation in the subapical part of 
shoots treated with chlormequat, parenchymatous tissue forming the cortex and pith layers constitutes 65 per cent, and vascular tissue as little as 35 per cent including 20 per cent xylem, along the cross section radius length. In spurs it is 60 , 40 and 25 per cent, respectively. Like in spurs the phloem to xylem width ratio is high (0.76) in the subapical part of the sprayed shoots. In the middle and basal parts of these shoots, particularly in strongly growing shoots, the per cent of the surface of the cortex layer and pith is smaller $(38-43 \%)$, and of xylem much higher $(42-50 \%)$. In these cases, therefore, the $\mathrm{Ph}: \mathrm{X}$ ratio is very low $(0.36-0.22 \%)$.

Distinct differences are noticeable not only in the width of the xylem layer, but also in its anatomical structure. In sprayed shoots, particularly in their subapical part and in spurs, many-row rays are frequent. The vascular elements are less numerous and their lumen is distinctly smaller than in the untreated shoots. Owing to this, the parenchyma has a higher participation in the xylem of the stem characterized by weak growth than in the stem engaged in vigorous elongation growth. There is no doubt that in shoots with growth inhibited by chlormequat or growing weakly by nature there is a high prevalence of living tissue capable of reserve substances accumulation and over lignified tissue fulfilling the role of mechanical and vascular tissue. It would seem that flow along the conducting elements of xylem is slowed down because of the reduced number of the latter elements, and particularly of their reduced diametre.

The differences in the anatomical structure of the internodes in pear shoots sprayed and not sprayed with chlormequat are similar to the results of other authors obtained in investigations on apple tree shoots sprayed with SADH (S c h u m a c h e r et al., 1967; H a l f a c r e and B a r d e n, 1968). In apple trees differences were also noted in the anatomical structure of leaves. The shoots sprayed with SADH have thicker leaves in which the cells of the spongy parenchyma are more loosely arranged and the cells of the palisade parenchyma are longer than in leaves of unsprayed shoots $(\mathrm{H} \mathrm{a} 1 \mathrm{f} \mathrm{a} \mathrm{c}$ e and $\mathrm{B}$ a $\mathrm{r} \mathrm{de} \mathrm{n}$, 1968; E a t o $n$ and $L u$ i, 1970).

Similar differences in the anatomical structure of the stem as in apple and pear trees sprayed with SADH or chlormequat were found by $\mathrm{B}$ e a $\mathrm{k} \mathrm{b}$ a $\mathrm{n} \mathrm{e}$ and R e n w ick (1936), B e a k b a e and Thom p o n (1939), $\mathrm{B}$ e a k b a n e (1941) in the anatomical structure of the root and stem of apple rootstock characterized by vigorous growth and dwarfs of group No. IX. These authors found in weakly growing rootstock as compared with the vigorous ones a higher ratio of the surface of cortex (all tissues outside the cambium jointly with the latter) to xylem and a greater participation of the surface of xylem rays and smaller of vessels and fibers in the secondary xylem layer on the cross section of the root and shoot. This was due to the much smaller diametre of the vessels and a twice larger surface of the xylem rays. Hence the conclusion of the authors that weakly growing rootstock has a higher per cent of living tissue surface and lower per cent of dead tissues than vigorously growing rootstock. 


\section{REFERENCES}

B e $a \mathrm{k} \mathrm{b}$ a $\mathrm{n}$ e B. A., 1941. The anatomical structure of some clonal and seedling apple rootstocks stem- and root-grafted with a scion variety. J. Pomol. Hort. Sci. 18: 344 - 367.

B e a k b a n e B. A., R e $n$ w i c k M. E., 1936. A preliminary report on the internal structure of the wood of No IX rootstock in relation to scion-rooting of apples. East Malling Res. Sta. Ann. Rep. for 1935: 101 - 106.

$\mathrm{B}$ e $\mathrm{a} \mathrm{k} \mathrm{b}$ a $\mathrm{n}$ e B. A., T h o $\mathrm{m} \mathrm{p}$ s o $\mathrm{n} \mathrm{C.} \mathrm{E.,} \mathrm{1939.} \mathrm{II.} \mathrm{The} \mathrm{internal} \mathrm{structure} \mathrm{of} \mathrm{the} \mathrm{roots} \mathrm{of} \mathrm{some}$ vigorous and some dwarfing apple rootstocks, and the correlation of structure with vigour. J. Pomol. Hort. Sci. 17: 141 - 149.

E a t o n W. G., L u i A., 1970. Leaf anatomy and shoot growth in a'compact strain of 'Delicious' apple compared to a normal strain treated with succinic acid 2,2-dimethylhydrazide. Hort. Sci. 5: $479-480$.

H a 1 f a c r e G. R., B a r d e $n$ A. J., 1968. Anatomical responses of apple leaf and stem tissues to succinic acid 2,2-dimethylhydrazide (Alar). Proc. Amer. Soc. Hort. Sci. 93: 25 - 32.

M a z u r o w a J., 1969 a. Badania porównawcze nad budową anatomiczną pędów dlugich i skróconych nie owocujących u jabłoni (Malus domestica Borb.). Zesz. nauk. S.G.G.W., Ogrodnictwo 5: 7-41.

M a z u r o w a J., 1969 b. Budowa anatomiczna pędów skróconych owocujących u jabłoni (Malus domestica Borb.). Zesz. nauk. S.G.G.W., Ogrodnictwo 5: 43 - 56.

$\mathrm{S} \mathrm{chu} \mathrm{m}$ a ch e r R., F a $\mathrm{n} \mathrm{k} \mathrm{ha} \mathrm{u} \mathrm{s} \mathrm{e} \mathrm{r} \mathrm{F.,} \mathrm{S} \mathrm{c} \mathrm{h} 1$ ä p f e r E., 1967. Einfluss des Heminstoffes Alar auf Fruchtentwicklung Schweiz. Landw. Forschung 6: 148 - 169.

W i 1 d e H. M., E d g e r t o n J. L., 1969. Some effects of growth retardant on shoot meristems of apple. J. Amer. Soc. 94: 118-122.

Czynniki wipływające na tworzenie się pąków kwiatowych u gruszy odm. 'Komisówka'. II. W pływ zahamowania wzrostu na budowę anatomiczną łodygi

\section{Streszczen ie}

Trzyletnie badania przeprowadzone na długopędach nie opryskanych i opryskanych CCC (chlorek 2-chloroetylotrójmetyloamoniowy) oraz nie opryskanych krótkopędach wykazały, że pędy silnie rosnące różnią się w swej budowie od pędów charakteryzujących się osłabionym wzrostem elongacyjnym, a więc od krótkopędów drzew kontrolnych i od długopędów opryskanych CCC.

W części górnej pędów opryskanych CCC, po całkowitym zakończeniu wzrostu elongacyjnego, następuje rozrastanie się kory pierwotnej i osłabienie przyrostu ksylemu wtórengo. W ksylemie występują wielorzędowe promienie rdzeniowe, a elementy przewodzące są mniej liczne i mają wyraźnie zmniejszoną szerokość. W wyniku tych zmian, w łodydze pędów charakteryzujących się słabym wzrostem udział elementów żywych jest znacznie większy niż w łodydze pędów silnie rosnących. 